\title{
Bogusław i Kamila Firkowiczowie oraz ich potomkowie
}

\author{
SZYMON PILECKI
}

Bogusław (karaimskie imię - Icchak Boas) Firkowicz urodził się w Trokach 17 czerwca 1865 r. jako trzecie dziecko Nisana (1826-1899), hazzana kienesy trockiej, i Sulamity (1824-1902). Cztery lata po powrocie z Krymu, gdzie w latach 1880-1885 zdobywał kwalifikacje przyszłego duchownego, 23 września 1889 r. ożenił się z Kamilą z Kobeckich (1873-1952). Początkowo mieszkali w domu rodziców, tuż „za mostem”, po prawej stronie ówczesnej ulicy Kowieńskiej, obecnie Karaimskiej.

Na przełomie XIX i XX wieku po przeciwnej stronie ulicy, naprzeciwko domu rodziców zbudowali okazały budynek murowany o bardzo ciekawej architekturze, w owych czasach niespotykanej na tym terenie. Budowę zakończyli w 1903 r. i zamieszkali w nowym domu z siedmiorgiem dzieci. Byli to: Szymon (Sienia) urodzony w 1893 roku; Józef (Osia), ur. 1896; Elżbieta (Liza), ur. 1898; Natalia, ur. 1901; Zuzanna, ur. 1903; Michał, ur. 1908 i Zinaida, ur. 1912 r. (ósme ich dziecko, Nisan Aleksander, ur. 1894 , zm. 1895, już wtedy nie żyło).

Równolegle ze sprawowaniem funkcji hazzana, od 1906 r. corocznie był wybierany na roczną kadencję członka 6-osobowego trockiego urzędu mieszkaniowego (Trokskoe kwartirnoe prisutstwie). Poza tym miał tytuł personalnego obywatela honorowego (ličnyj početnyj grażdanin)

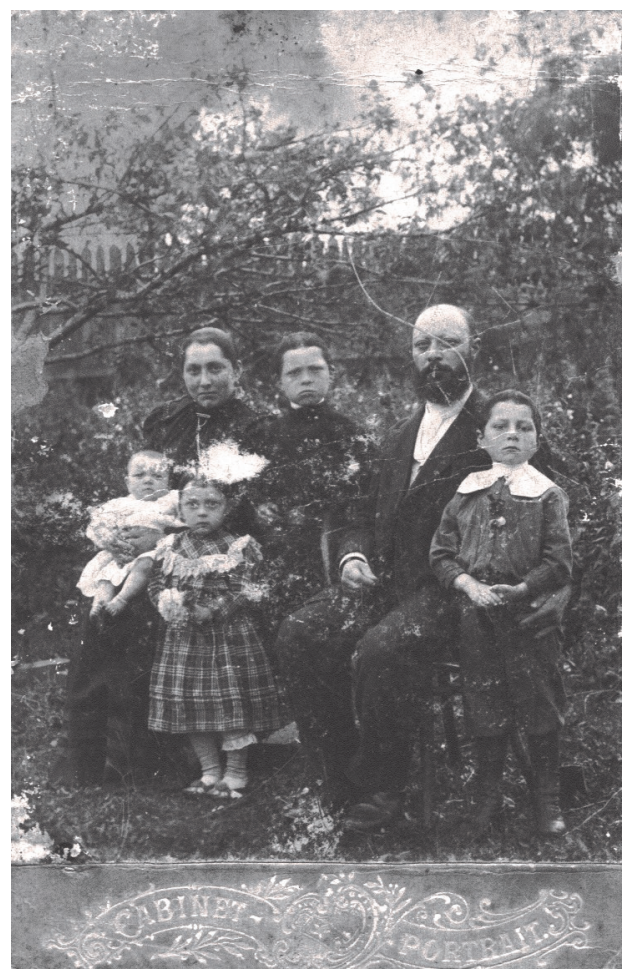

Bogusław i Kamila z Józefem, Elżbieta, Nataliq i maleńkq Zuzanną 
Bogusław jako p. o. hachana trockiego i jedyny przedstawiciel Karaimów z sześciu tzw. guberni północno-zachodnich, po zatwierdzeniu przez władze państwowe uczestniczył w pierwszym w Rosji narodowym zjeździe delegatów gmin karaimskich, który w dniach 1-9 listopada 1910 r. obradował w Eupatorii. Pracował tam w kilku komisjach, formułujących opinie i zalecenia uchwalane przez zjazd. Były to ważne decyzje, dotyczące m.in. prawa małżeńskiego, szkolnictwa itd. 0 problemach nurtujących przed 100 laty naszą społeczność i o ówczesnych dżymatach mówią obszerne sprawozdania. (Kararaimskaâ Žizn', nr I, 1911, s. 72-85). Czytamy tam m. in.:

„Zgodnie z p. 5 programu o ustaleniu składek na utrzymanie zarzqdu duchownego i inne potrzeby, zjazd zdecydował ogólnq sumę wydatków podzielić na 100 części (arecha), przy czym coroczne wkłady poszczególnych dżymatów miały wynosić:

Eupatoria - 25 części; Feodosja -- 18; Odessa -- 14; Petersburg - 6; Moskwa - 5; Kijów - 5; Sewastopol - 4; Nikołajew - 4; Symferopol - 4; Charków - 3; Melitopol 3; Jekatierinosław - 3; Cherson - 2; Berdiańsk - 1; Jałta - 1; Noworosyjsk -1; Kremieńczug - 1/2; Karasubazar - 1/2; Połtawa-1/2; Niżnij-Nowgorod - 1/2; Ryga - 1/2; Libawa - 1/2; Orzeł - 1/2; Skadowsk - 1/2. Mogącq powstawać nadwyżkę (106 części zamiast 100) przeznaczyć na pokrycie niedoborów ${ }^{1}$.

Zjazd zdecydował podwyższyć roczne uposażenie hachana taurydzko-odeskiego z 4000 do 5200 rb. i zalecić ubezpieczenie na życie hazzanów na przynajmniej 20003000 rb., a szamaszów i nauczycieli na $1000 \mathrm{rb}$.

P. o. hachana trockiego wyjaśnit, że $w$ trockim hachanacie sytuacja materialna hazzanów, szczególnie łuckiego, poniewieskiego i wileńskiego, jest znacznie trudniejsza, co potwierdzili także inni uczestnicy zjazdu. Zjazd uznał niezbędnq konieczność polepszenia sytuacji hazzanów $w$ rejonie trockim przez ubezpieczenia, a także przekazanie przydziału".

W 1913 r. stanął na czele 3-osobowej oficjalnej delegacji (wraz z Józefem Łopatto z Wilna i Ananiaszem Chorczenko z Kijowa), która uczestniczyła w podnio-

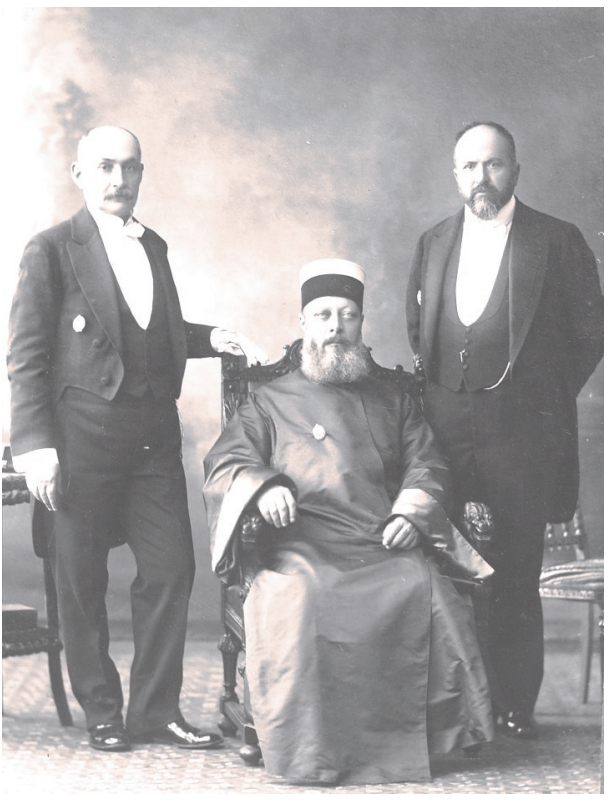

Karaimska delegacja na uroczyści 300-lecia panowania dynastii Romanowych

${ }^{1}$ Ten podział odzwierciedla zapewne liczebność oraz/lub - być może - zasobność dżymatów, nie obejmuje jednak hachamatu trockiego. Skądinąd wiadomo też, że w Eupatorii mieszkało w tym czasie ok. 2500 Karaimów, a więc na podstawie przytoczonego rozdziału składek można ocenić przybliżoną liczebność wymienionych dżymatów (1 składka przypada na około 100 osób). 
słych uroczystościach obchodów w St. Petersburgu 300-lecia panowania dynastii Romanowych, zapoczątkowanego w 1613 r. wstąpieniem na tron cara Michała.

Losy rodziny - mimo tych wszystkich honorów, jakie spotykały Bogusława nie były łatwe. Po wybuchu I wojny światowej wobec zbliżania się frontu niemieckiego i zarządzenia władz carskich nakazujących ewakuację w głąb Rosji, uwożąc ze sobą archiwum trockiego dżymatu i hachanatu oraz mienie kienesy, w lipcu 1915 r. wyjechali do Ostrowa koło Pskowa, gdzie istniał bratni dżymat i od 1887 r. mieszkała z mężem Adela Robaczewska (1866-1937), młodsza siostra Bogusława. W dwa miesiące później, podczas dorocznego święta Boszatłych, całodobowego postu i odprawiania całodziennych uroczystych modłów, pod koniec dnia przysiadł zmęczony, co miało się stać przyczyną skrętu jelit. Tradycyjnie suta tego dnia kolacja znacznie pogorszyła jego stan

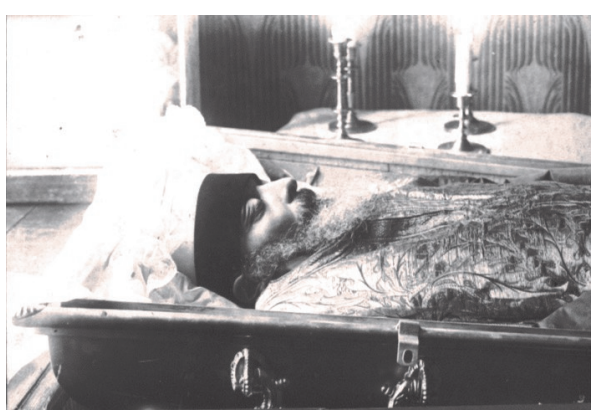

b.p. Bogusław Firkowicz, rok 1915 i po trzech dniach zmarł. Te dni, początkowo wypełnione konsultacjami lekarskimi, a później porządkowaniem spraw doczesnych, sporządzaniem testamentów i wreszcie świadomym oczekiwaniem niechybnie zbliżającego się końca, były dniami o niewymownym tragizmie dotykającym chorego (do ostatka w pełni świadomego), jego rodzinę i cały dżymat. Został pochowany na cmentarzu karaimskim w Pskowie, a owdowiała żona Bogusława, Kamila, sporządzając w 1934 r. testament, zobowiązała najstarszego żyjącego syna, Józefa, do sprowadzenia szczątków ojca do Trok, co jednak

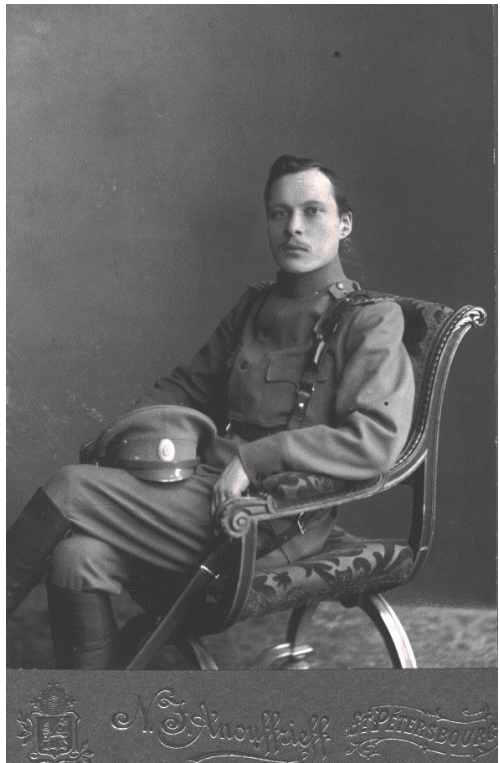

Szymon Firkowicz, rok 1917 okazało się niemożliwe.

W 1916 r. wdowa z gromadką dzieci przeniosła się do Petersburga. Najstarszy syn właśnie w Petersburgu kończył wojskową akademię medyczną i wkrótce został skierowany na front, Józef i Elżbieta już pracowali - syn w porcie, córka w kancelarii notariusza. Trzeba tu wspomnieć, że Szymon i Elżbieta ukończyli gimnazja odznaczeni złotymi medalami - uzyskując same bardzo dobre oceny, z tym jednak, że Elżbiecie złota nie wręczono, ograniczono się do dyplomu, lecz medal otrzymany przez Szymona przechowywany jest jako cenna pamiątka rodzinna. Jest to okazały krążek o średnicy $32,7 \mathrm{~mm}$ i grubości (nieco zwiększonej po obwodzie) 2,3 mm, z wizerunkiem głów pary carskiej po jednej stronie oraz gałązką laurową i napisem „1812 ПРЕУСПЕВАЮЩЕМУ 1912” - po drugiej. 
W 1918 r. przyszedł kolejny cios - nadszedł telegram zawiadamiający o śmierci Szymona, który w warunkach frontowych nie przetrzymał tyfusu.

Nastroje w Petersburgu stawały się coraz bardziej rewolucyjne, brakowało żywności - jedynym ratunkiem były wyprawy starszych dzieci na wieś i związana z tym konieczność nieustannego wymykania się licznym kontrolom i konfiskatom. Mimo tych trudności wywołanych wojną, rewolucjami i głodem, życie w stolicy imperium miało też swe uroki, zwłaszcza możliwość korzystania z imprez kulturalnych, teatrów i koncertów, opowiadaniom o których następne pokolenie miało możność się przysłuchiwać w latach międzywojennych. Ponieważ petersburska gmina karaimska była liczna, stale odbywały się różnego rodzaju spotkania okolicznościowe. Józef poznał Rosjankę niezwykłej urody, która dopiero po któryś tam oświadczynach zgodziła się na małżeństwo. Elżbieta pozostała wierna trockiej sympatii i pokonując wielkie ówczesne trudności komunikacyjne, poje-

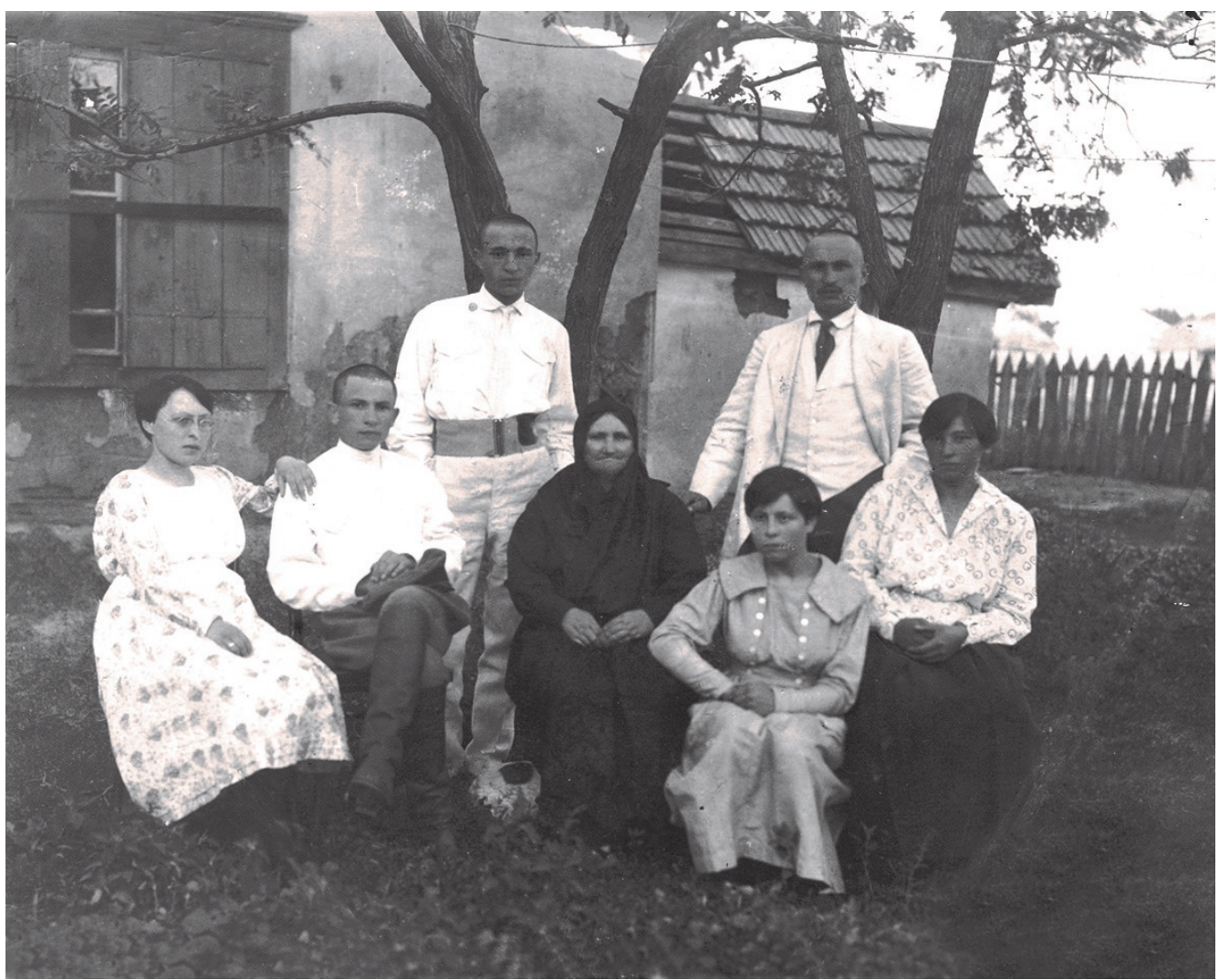

Rodzina Pileckich w Kremiennoj. rok 1920

chała do Kremiennoj koło Charkowa, dokąd pęd ewakuacyjny zagnał Pileckich, dzierżawców karaimskiego majątku w Malowance koło Trok. Jej ślub z Aleksandrem Pileckim odbył się wiosną 1921 r. Traf zrządził, że w Kremiennoj była średnia szkoła leśna, dzięki czemu dwaj bracia, Aleksander i Michał, zdobyli zawód leśniczego. I tu ciekawostka, przekazana przez Zofię Dubińską - wiadomość o ist- 
nieniu tej szkoły dotarła do Pileckich dzięki temu, że ktoś z domowników usłyszał na bazarze rozmowę $w$ języku polskim. Po wielokrotnych zmianach władz „białych” i „czerwonych” udało im się przyjechać do Trok dopiero w $1923 \mathrm{r}$.

Kamila z dziećmi do Trok powróciła w 1920 r., gdzie po pięciu latach nieobecności wszystko trzeba było zaczynać od zera. Jedyne co mieli, to ogrody i domy jako tako nadające się do zamieszkania, chociaż silnie zdewastowane wskutek kilkakrotnego przechodzenia frontów wojennych, różnych armii i rewolucji. W 1920 r. Natalia poślubiła Rafała Abkowicza. Następna podobna uroczystość miała miejsce w 1929 r. - Zuzanna wyszła za mąż za Gabriela (Garę) Robaczewskiego, a w 1935 r. Michał ożenił się z Tamarą Szpakowską.

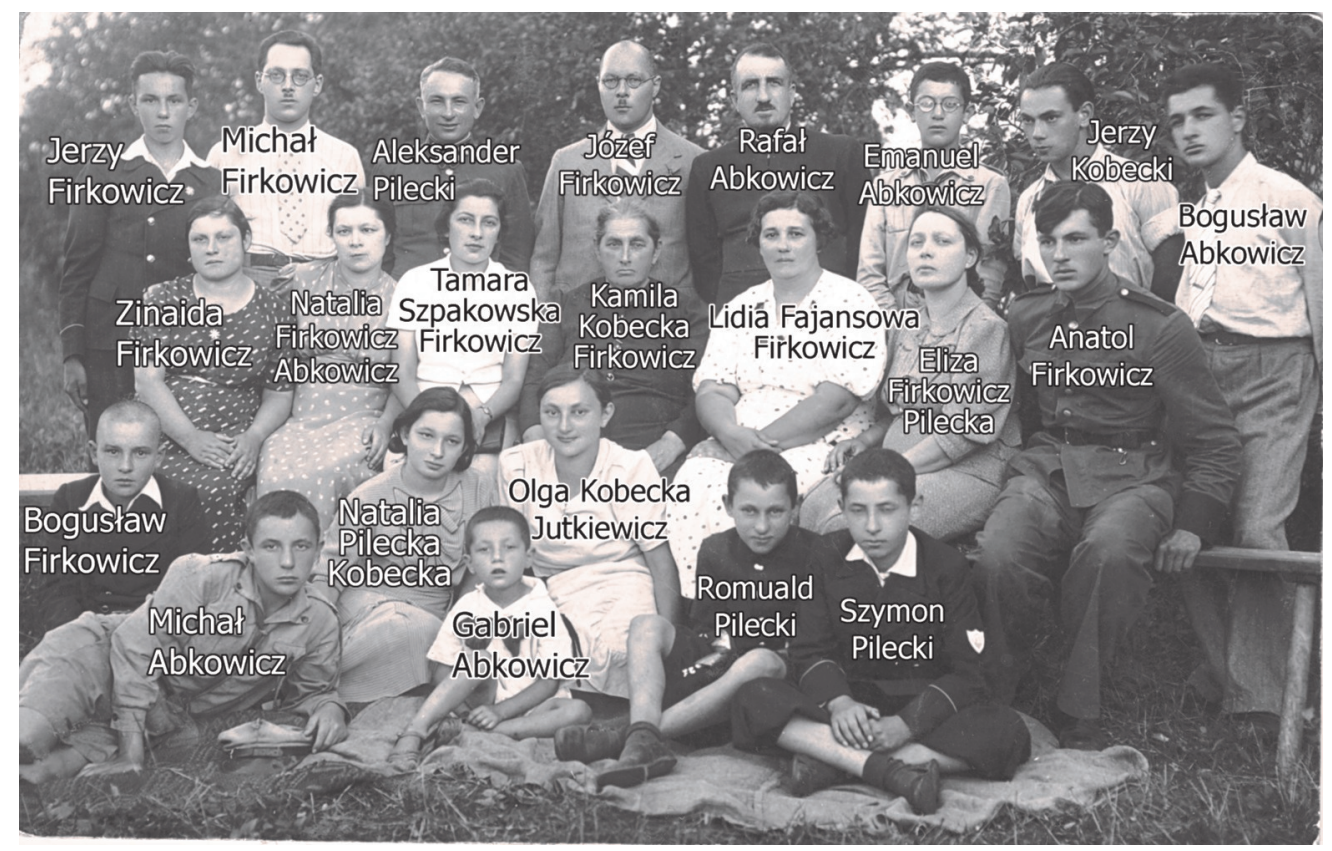

Kamila Firkowiczowa (Bogusiowa) z dziećmi, wnukami i bratankami, rok 1938

Prześledźmy pokrótce losy członków rodziny w następnych pokoleniach.

Pierwsze lata po powrocie były niezwykle trudne - wdowa z dziećmi, bez stałych dochodów, z koniecznością napraw dewastacji wojennych bez pomocy męskiej ręki... Były wprawdzie oprócz domu murowanego, w którym zamieszkała, jeszcze cztery domy nadające się do wynajęcia, ale wymagające remontów i nie przynoszące zadowalających dochodów, tym bardziej, że ogólny poziom zasobności mieszkańców Trok w okresie międzywojennym był bardzo niski. Na tle tego raczej biednego otoczenia stosunkowo dobrze sobie radziła, latem dzięki krówkom, każdego ranka wyganianym na cały dzień przez wspólnego pastucha oznajmiającego pochód stada dęciem w specjalną, długą trąbę, a także dzięki wysyłanym na targ do Wilna zbiorom ogórków, jesienią zaś gromadząc w stodole zebrane przez tzw. połownika zbiory zboża z przypadającej jej i synowi 
części „pól karaimskich”. To skromne, ale spokojne życie okresu międzywojennego uległo radykalnemu pogorszeniu niedługo po wybuchu wojny. W $1941 \mathrm{r}$. wszystkie domy zostały znacjonalizowane, a Kamilę z córką Ziną wkrótce wyrzucono z ich murowanego domu, zajęły więc jeden pokój $\mathrm{w}$ domu zbudowanym jeszcze przez teścia, Nisana, po przeciwnej stronie ulicy. Stan ten odmienił się podczas okupacji niemieckiej w 1941 r. i Kamila znów zamieszkała w swoim domu, ale w 1947 r. po ponownym wyrzuceniu z domu Kamila doznała wylewu krwi do mózgu, paraliżu i utraty mowy. W tym stanie, przykuta do łóżka pozostała aż do śmierci w 1952 r. początkowo pod opieką córki Elżbiety w leśniczówce w Leśnikach (Miszkiniai), potem córki Ziny w domu Zuni i Gary Robaczewskich w Trokach.

Syn Kamili i Bogusława, Józef, jeszcze w Petersburgu ożeniony z Rosjanką Lidią, po powrocie kilka lat przebywał w Trokach, a następnie - jako chemik z wykształcenia - zatrudnił się w cukrowni w Krasińcu na Mazowszu. Mieli trzech synów: Anatoliusza (1921-1966), Jerzego (1923-

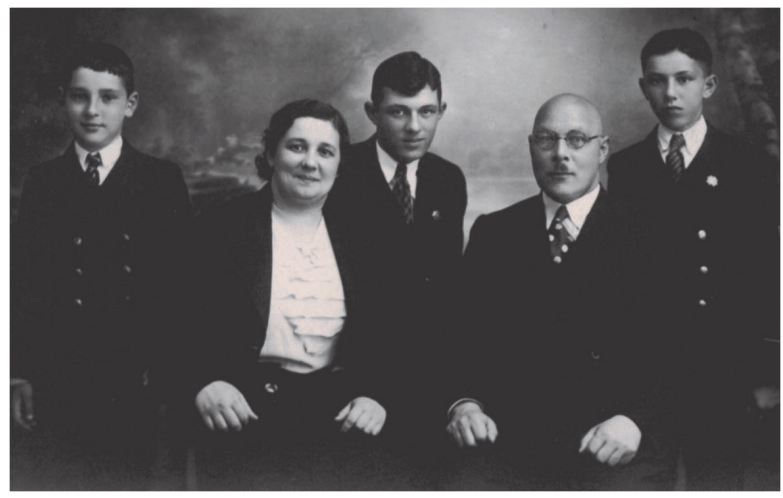

Józef Firkowicz z rodzina, rok 1937 1992) i Bogusława (1927-1970). Często przyjeżdżali do Trok, czy to na święta wielkanocne, czy na jesienne (Boszatłych), lub po prostu na wakacje - ostatni raz latem 1938 r. Jako że chłopaki były chwackie, a mówiły z dziwnie w Trokach brzmiącym mazowieckim akcentem, stanowiły wielką atrakcję dla naszych panien - niestety, wakacje trwały tak krótko... W Krasińcu mieszkali do 1945 r., kiedy to Józefa powołano na stanowisko dyrektora cukrowni w Otmuchowie koło Nysy, na Ziemiach Odzyskanych, którą trzeba było jak najszybciej uruchomić, „aby Czesi zza pobliskiej granicy widzieli, że już gospodarzymy”. Niedługo później - po lokalnych nieporozumieniach - został przeniesiony do pobliskiej cukrowni w Łagiewnikach, a wkrótce porzucił branżę cukrowniczą, przeszedł do budownictwa przemysłowego i cała rodzina zamieszkała we Wrocławiu. Na budowie doznał poważnego wypadku - coś spadło mu na głowę i wybiło otwór (!) w czaszce - operacyjnie założono mu złota płytkę, by zasłonić ubytek. Po 1955 r., gdy odwiedziny krewnych w ZSRR stały się możliwe, bywali w Trokach, a także w Leningradzie, gdzie Lidia odnalazła nawet swego brata. Nie przyjeżdżali już jednak w pełnym składzie, cała rodziną, jak w 1938 r. Po którymś pobycie (zapewne ostatnim, latem 1963 r.) Józef opowiadał, jak opływał łódką całe jezioro Galwie, snując oczywiście przy tym wspomnienia z przeszłości... Skądinąd słyszałem, jak to ongiś synowie szarpali nerwy matki Kamili, demonstracyjnie skacząc z łodzi do wody. Z czasem Józef zaczął narzekać na kłopoty z sercem; po przejściu kilkuset metrów musiał przystawać, aby odpocząć. 4 paź- 
dziernika 1963 r. jego serce nagle odmówiło posłuszeństwa, kiedy leżąc w szpitalnym łóżku, właśnie wesoło rozmawiał z lekarzem. Został pochowany w Warszawie.

Lidia po śmierci męża zajmowała się wnukami, nadal uczestniczyła w prowadzeniu kiosku z prasą, pamiątkami i drobiazgami, założonemu jeszcze z mężem i z teściami Bogusława. Z powodu pogarszającego się stanu zdrowia bywała kierowana do sanatoriów, a wracając z nich z reguły zajeżdżała do Warszawy, nad mogiły męża, a później i syna Anatola. Zmarła w 1970 r., pochowana jest we Wrocławiu.

Najstarszy syn Józefa, Anatol, pracował jako księgowy w centrali przemysłu mięsnego we Wrocławiu. W 1948 r. ożenił się z Janiną Szulimowicz z Halicza, farmaceutką. W wieku zaledwie 45 lat zmarł nagle, również na zawał serca, na dworcu kolejowym w Warszawie, gdy jechał w odwiedziny do Trok i Wilna. Janina zmarła w 1979 r. Oboje pochowani są w Warszawie. Ich syn Jerzy (ur. w 1949) jest żonaty z Anną, ma córkę Małgorzatę.

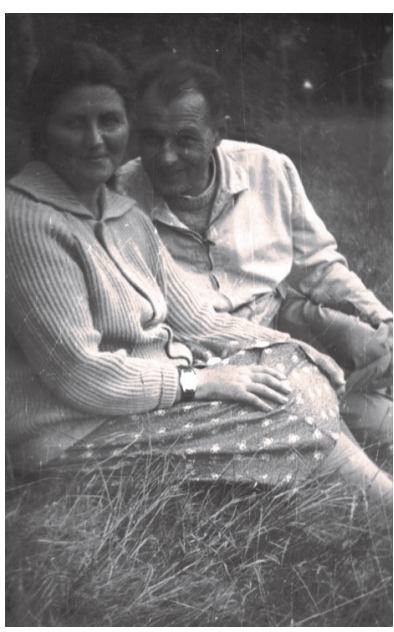

Janina i Anatol Firkowicz, rok ok. 1960

Drugi syn Józefa, Jerzy, po ukończeniu politechniki pracował i mieszkał w Jaworze koło Wrocławia. Ożeniony z Laurencją, dorobił się licznej rodziny ma trzech synów: Cezarego (ur. 1954), Piotra (ur. 1958) i Wojciecha (ur. 1960), doczekał się pięciu wnuczek i pięciorga prawnucząt. Zmarł na serce, pochowany w Jaworze.

Najmłodszy z synów Józefa, Bogusław, w dzieciństwie zwany Laba, pracował w budownictwie we Wrocławiu. Ożenił się z Wirginią, miał dwóch synów: Andrzeja (ur. 1951) i Witolda (ur. 1958). Zmarł w wieku zaledwie 43 lat, pochowany jest we Wrocławiu.

Najstarsza z córek Bogusława i Kamili Firkowiczów, Elżbieta po powrocie w 1923 r. z całą rodziną Pileckich i córką Natalią (ur. 1922) z Kremiennoj, wkrótce z mężemleśniczym zamieszkała na odludziu, w głębi puszczy Bersztańskiej, 25 km od stacji Marcinkańce. Dla kogoś, kto jeszcze niedawno bywał $\mathrm{w}$ petersburskich teatrach, wyrywanie perzu w zakładanym ogrodzie nie było zbyt atrakcyjnym zajęciem. Urodziła synów: Szymona Bogusława (1925) i Romualda (1927-1972). Kiedy dzieci miały pójść do szkoły, męża przeniesiono bliżej miasta - kolejno do Landwarowa,

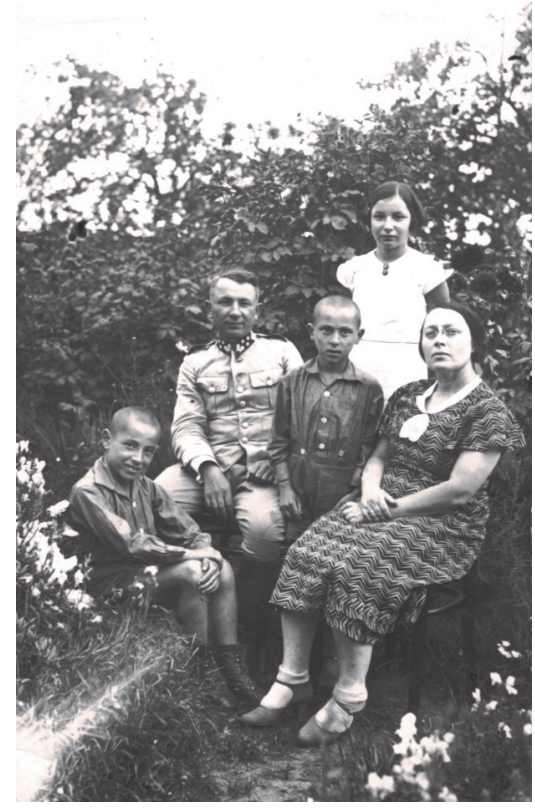

Aleksander i Elżbieta Pileccy z dziećmi, rok ok. 1932 
Raczkun i Leśnik. Ta ostatnia miejscowość miała najwięcej zalet - duża leśniczówka położona tuż w pobliżu stacji kolejowej, co umożliwiało dojazd do Wilna. Mieszkali tam do 1952 r., kiedy Aleksander awansował na dyrektora leschozu. Przenieśli się $\mathrm{w}$ pobliże Landwarowa, a po przejściu na emeryturę w październiku 1957 r. - do swego domku w Trokach. Kilka razy odwiedzali syna Szymona w Warszawie. W marcu 1971 r. obchodzili złote wesele - w niezbyt wesołych nastrojach, gdyż Aleksander był na tę uroczystość urlopowany ze szpitala. Zmarł niecałe dwa miesiące później wskutek komplikacji po operacji nerek. Niedługo po tym Elżbieta przeżyła kolejny dramat - straszliwą chorobę (nowotwór gardła) syna Romualda i jego śmierć w grudniu 1972 r. Ona sama, dopóki zdrowie pozwalało, gospodarzyła w swym ogrodzie (kochała zwłaszcza kwiaty), później prze-

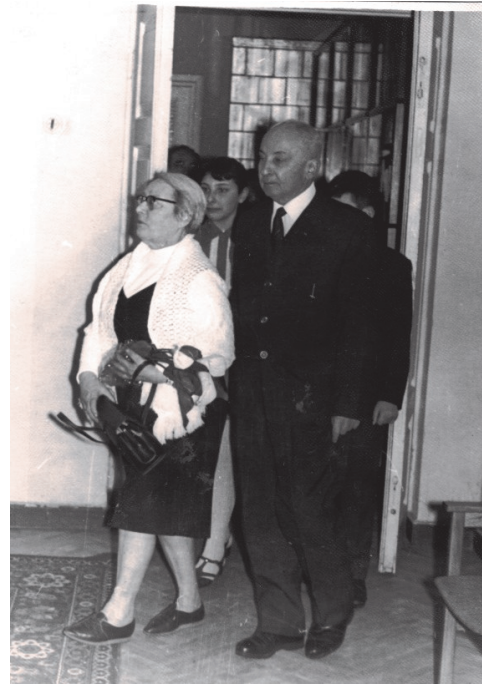

Złote wesele Elżbiety i Aleksandra Pileckich, rok 1971 bywała u córki Natalii w Wilnie. Zmarła w1981 r. Tak jak mąż i syn, została pochowana w Trokach.

Córka Elżbiety, Natalia, po ukończeniu gimnazjum zaczęła studiować chemię na wileńskim uniwersytecie. W sierpniu 1942 r. wyszła za mąż za Jerzego Kobeckiego (1921-1986). Mieszkali w Wilnie. W końcu 1944 r. NKWD aresztowało Jerzego „w kotle”. Został wywieziony do obozu, skąd wyszedł dopiero w 1948 r. Po powrocie zatrudnił się w leśnictwie, mieszkali w Bobrówce i Trokach (Natalia pracowała wówczas w szpitalu). Jerzy ukończył akademię leśną i w 1962 r. został przeniesiony do ministerstwa leśnictwa. W 1966 r. zamieszkali w Wilnie (od 1968 r. na ul. Minties). Synowie Natalii i Jerzego to Jurij (19451999) i Roman (ur. 1949). Jurij, żonaty z Galiną (ur. 1946) jest ojcem Awenira (ur. 1977) i Mirosława (ur. 1982); w 1989 r. wraz z żoną i synami wyemigrował do Szwecji, gdzie wkrótce zajął eksponowane stanowisko w koncernie Ericssona. Niestety, zachorował na raka i przedwcześnie osierocił rodzinę. Synowie poszli w ślady ojca - zostali fizykami: Awenir doktoryzuje się w Goeteborgu, Mirosław zaś kończy studia w Londynie. Drugi syn Natalii, Roman był żonaty z Eugenią Maszkiewicz. Z tego związku narodzili się synowie: Aleksander (ur. 1973), Władimir (ur. 1975) i Timur (ur. 1982), a z drugiego małżeństwa z Czesławą - syn Tomasz (1999). Roman doczekał się już wnucząt (czyli prapraprawnucząt Bogusława i Kamili Firkowiczów!): Kamila (1998), syna Aleksandra i Anny z Maleckich (ur. 1971) oraz Dominiki (ur. 2002), córki Władimira i Rajmondy z Rojeckich (ur. 1977).

Szymon Bogusław Pilecki², starszy z synów Elżbiety, w 1945 r. skończył w Wilnie szkołę techniczną i jeden rok studiów, a będąc zmuszany przez NKWD

2Pilecki S., Z kresów wschodnich ku politechnice wrocławskiej, Awazymyz, nr 1 (12)/2006, s. 3-7. 
do współpracy i donosów, aby uniknąć nacisków, zdecydował się wyjechać do Polski. Osiedlił się we Wrocławiu. Ukończył politechnikę, pracował w fabryce i na politechnice. Był też pilotem szybowcowym i samolotowym oraz skoczkiem spadochronowym, W grudniu 1951 r. został powołany do służby wojskowej i zatrudniony w Wojskowej Akademii Technicznej w Warszawie. Od 1970 r. pracował w Polskiej Akademii Nauk. Zdobywał kolejne stopnie wojskowe i naukowe, dosłużywszy się rangi pułkownika i stopnia profesora. Jest aktywnym karaimskim działaczem społecznym - współpracował z Józefem Sulimowiczem w tworzeniu statutu Karaimskiego Związku Religijnego, a po jego zatwierdzeniu przez władze, w 1974 r. i ponownie w 2003 r. został wybrany przewodniczącym zarządu KZR. Walnie przyczynił się do powiększenia cmentarza karaimskiego w Warszawie, do zbudowania jego ogrodzenia i uzyskania wsparcia finansowego na ten cel. W 1995 r. przeszedł na emeryturę. Rodziców w Trokach mógł odwiedzić po raz pierwszy dopiero w 1955 r. Ożenił się tam z Anną Rojecką (19321992) z Poniewieża, jednak w 1963 r. rozwiedli się. W 1959 r. przyszła na świat ich córka Irena, która w 1984 r. wyszła za mąż za Jana Jaroszyńskiego (ur. 1957), fizyka, obecnie od kilku lat pracującego w USA. Ma z nim syna Michała (ur. 1984), kończącego w Warszawie studia politechniczne. W 1999 r. Szymon Pilecki poślubił Jadwigę (ur. 1943), mieszkają w swym domku w Warszawie.

Młodszy syn Elżbiety, Romuald (1927-1972), pracował w przemyśle maszynowym. W 1955 r. ożenił się z Ireną Jutkiewicz (1934-2005), nauczycielką. Oboje pracowali i mieszkali w Landwarowie, gdzie zbudowali swój dom. Starszy z dwóch ich synów, Aleksander (ur. 1956), ożenił się z Marią Pilecką (ur. 1956) z Gdańska, wyjechał do Polski, zajmuje się biznesem. Jest ojcem Anny (ur. 1981), aktualnie mieszkającej w Londynie. Młodszy syn, Włodzimierz (ur. 1959), ożenił się z Rutą Jutkiewicz (ur. 1957). Jest dyrektorem szkoły w Landwarowie, ojcem syna Andriusa (ur. 1993) i córki Edity (ur. 1995).

Powróćmy do dzieci Bogusława i Kamili Firkowiczów i prześledźmy losy pozostałych. Ich czwarte dziecko, a druga córka, Natalia (1901-1986), jak już wspominaliśmy, po powrocie z Petersburga poślubiła w 1920 r. Rafała Abkowicza (1896-1992), hazzana i nauczyciela religii i języka karaimskiego. Mieli czterech synów i zmarłą w dzieciństwie córkę. Byli to: Bogusław (1921-2004), Emanuel (ur. 1923), Michał (1925-1983), Anna Pelagia (1928-1930) oraz Gabriel (ur. 1934).

Jak podaje Emanuel Abkowicz, jego ojciec Rafał, syn Abrahama Samuela i Estery, ukończył karaimską i rosyjską szkołę w Trokach. Jego nauczycielem w tej pierwszej był właśnie Bogusław Firkowicz. W 1915 r. jako 19-latek zgłosił się na ochotnika do carskiej armii i został skierowany do szkoły oficerskiej w Moskwie, którą ukończył w 1917 r. Następnie wcielono go do 177 Izborskiego pułku piechoty, w szeregach którego brał udział w I wojnie światowej, walcząc na froncie północnym pod Rygą. Przebywał tam do wybuchu rewolucji, a w grudniu 1917 r. został zdemobilizowany. Po demobilizacji trafił do Moskwy, o czym do września 1918 r. był zastępcą naczelnika więzienia w mieście Kaszyra w obwodzie tulskim. W październiku 1918 r. po uzyskaniu stosownych dokumentów 


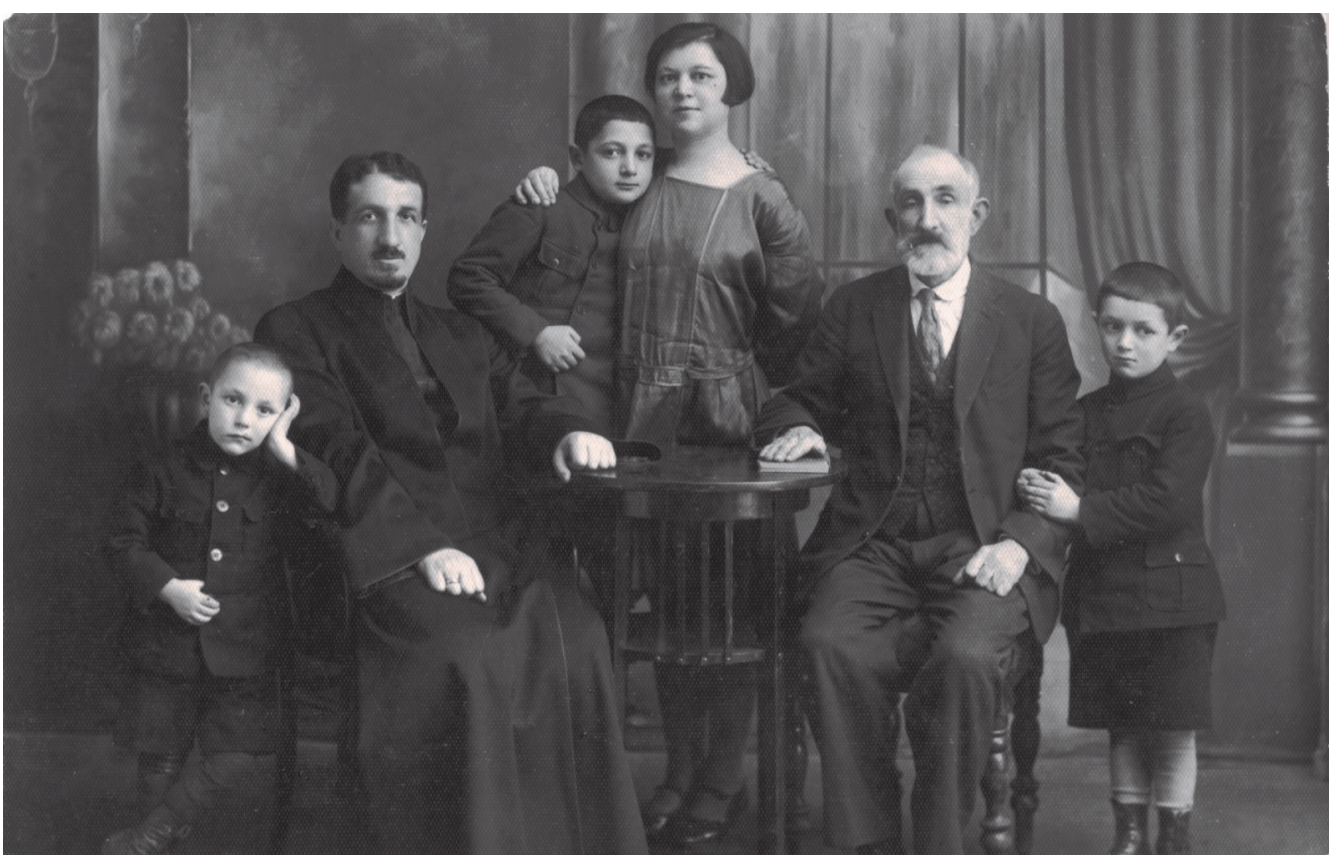

Rodzina Rafała i Natalii Abkowiczów, rok 1928

podjął decyzję o powrocie do Trok. W międzyczasie odnalazł w Charkowie ewakuowaną rodzinę, tj. ojca, ciotkę Annę Kapłanowską, brata Józefa i siostrę Ninę. Po długiej i wyczerpującej podróży powrócili do Trok w 1919 r. Rafał zaczął od podstaw organizować życie Karaimów. Otworzył szkołę (midrasz), w której zebrał młodzież karaimską z Trok, uczęszczającą w tym czasie do innych szkół. Nauczał religii i języka karaimskiego. W 1919 r. został wybrany na stanowisko hazzana trockiego, jednak w 1920 r. ze względu na trudne warunki materialne (właśnie ożenił się z Natalią Firkowicz) był zmuszony zrzec się tej funkcji. Podjął pracę w spółdzielni „Przyszłość” w Trokach jako pomocnik księgowego, następnie w latach 1925 - 1928 pracował w magistracie trockim jako sekretarz. Jednocześnie w latach 1918 -1925 był nauczycielem religii karaimskiej w Trokach, a w latach 1927-1929 nauczycielem języka karaimskiego i religii karaimskiej w Wilnie. W 1928 r. po wyborze na hachana Karaimów polsko-litewskich Seraji Szapszała i jego przybyciu do Polski, Rafał Abkowicz został wydelegowany na stanowisko hazzana i nauczyciela religii do Łucka, gdzie przebywał do 1938 r. Następnie objął stanowisko hazzana w Wilnie i pełnił tę funkcję do 1946 r. Ponieważ jego synowie, Bogusław i Michał w 1944 r. zaciągnęli się ochotniczo do wojska polskiego, a po wojnie mieli prawo sprowadzić rodzinę do Polski, Rafał i Natalia wraz z pozostałymi dwoma synami odbyli dwutygodniową podróż (od 15 do 30.03.1946 r.) transportem repatriacyjnym z Wilna przez Olsztyn, Łódź, Opole, Wrocław do Otmuchowa, gdzie dyrektorem cukrowni był Józef Firkowicz, starszy brat Natalii. Rafał podjął pracę księgowego w cukrowni Łagiewniki. W lipcu 1946 wraz z żoną i najmłodszym synem Gabrielem przenieśli się do Wrocławia, gdzie zamieszkali u Efrema Dubińskiego, farmaceuty 
(przedwojennego właściciela apteki w pobliżu Wilna) i jego siostry Zofii, zajmując dwa pokoje. Warto tu dodać, że w tym dużym mieszkaniu pod koniec 1946 r. odbył się pierwszy powojenny zjazd karaimski w Polsce, na którym podjęto szereg postanowień istotnych dla odbudowy karaimskiego życia społecznego. Z czasem Dubińscy przenieśli się do Częstochowy, gdzie mieszkały dwie ich siostry. Hazzan Abkowicz uzyskał przydział na dwa opuszczone przez nich pokoje, prze-

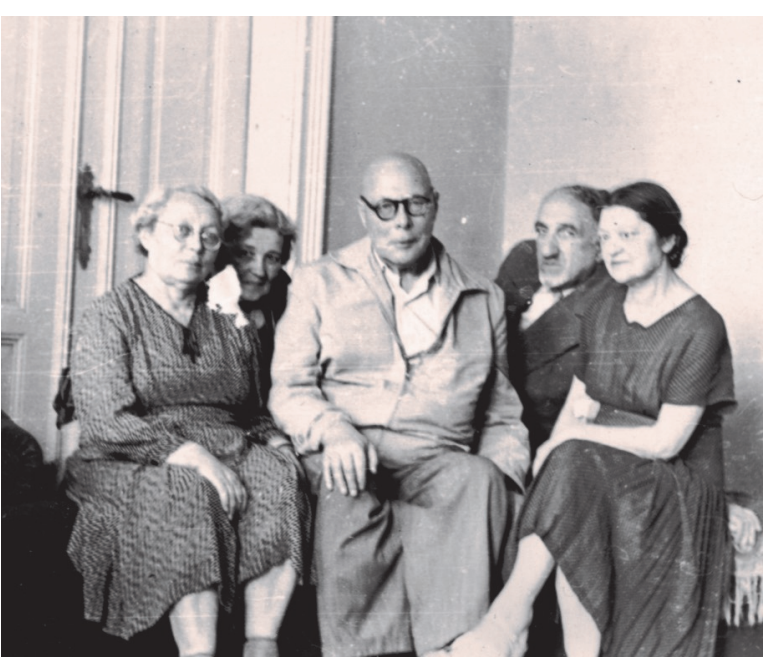

U Abkowiczów we Wrocławiu, rok 1959 znaczając je na kienesę. Gdy po wyprowadzce Bogusława Abkowicza zwolnił się jeszcze jedne pokój, został on przeznaczony na biuro. W pomieszczeniach tych w miarę potrzeb Rafał Abkowicz odprawiał modły. W pierwszych dziesięcioleciach potrzeby te były znaczne, z czasem jednak zmalały wskutek zmniejszania się liczebności dżymatu. Wtedy mieszkanie zamieniono na mniejsze, ale wygodniejsze. Równolegle Rafał od 1946 r. pracował zawodowo jako główny księgowy i na tym stanowisku doczekał emerytury w 1958 r. Utrzymywanie się wyłącznie z funkcji hazzana nie było bowiem możliwe z powodu niewystarczającej zasobności nielicznej gminy karaimskiej oraz braku, w przeciwieństwie do okresu przedwojennego, wsparcia finansowego ze strony władz.

Syn Rafała i Natalii, Bogusław, w 1937 r. wstąpił do gimnazjum. W 1940 r. nie ukończywszy 3. klasy, opuścił szkołę i do lipca 1944 r. pracował w tartaku w Leśnikach pod Trokami jako księgowy, mieszkając u wujostwa, Elżbiety i Aleksandra Pileckich. Następnie wstąpił na ochotnika do wojska polskiego, gdzie służył do końca wojny i został zdemobilizowany w 1945. Po wojnie podjął pracę w cukrowni Kondratowice na stanowisku kierownika personalnego. W 1948 r. przeniósł się do Wrocławia, gdzie mieszkali jego rodzice, ukończył szkolę średnią oraz studnia prawnicze. Ożenił się w 1963 r. w Trokach z Zofią Juchniewicz (ur. 1931), nauczycielką. Mają dwie córki: Mariolę (ur. 1964), kierownika biblioteki Wydziału LekarskoStomatologicznego AM we

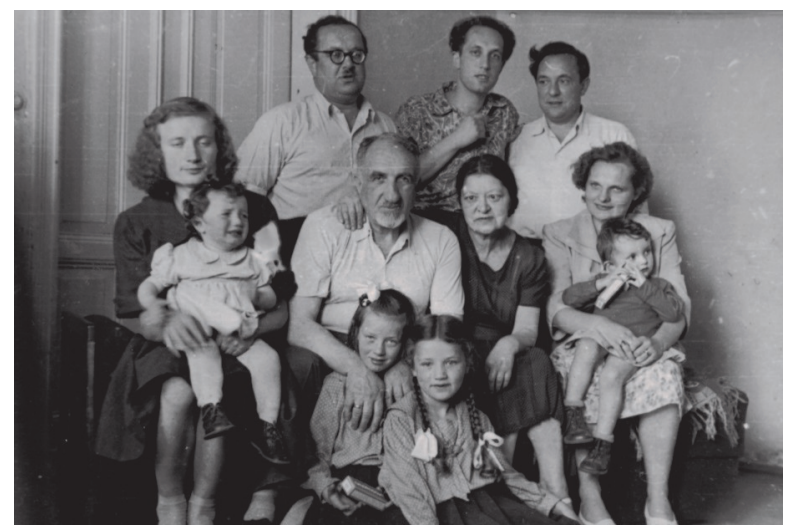

Rodzina Abkowiczów, rok 1959 
Wrocławiu, karaimoznawcę oraz przewodniczącą zarządu Związku Karaimów Polskich i mieszkającą obecnie w Warszawie Annę (ur. 1968), doktora nauk matematycznych i bankowca. Bogusław pracował w Narodowym Banku Polskim we Wrocławiu na stanowisku wicedyrektora IV Oddziału NBP. W 1998 r. przeszedł na emeryturę. Zmarł w 2004 r. i został pochowany na cmentarzu karaimskim w Warszawie, gdzie spoczywają także jego rodzice.

Emanuel Abkowicz (Maniuk) po ukończeniu 7 klas szkoły podstawowej wstąpił do gimnazjum ogrodniczego w Wilnie, jednak po wybuchu wojny przerwał naukę. W latach 1940-1942 uczęszczał do szkoły rolniczej, a po jej ukończeniu pracował jako agrotechnik w gminie Vievis na Litwie, później w gminie trockiej, w 1944 wyjechał do Zośli, gdzie pracował do lutego 1946 r. na stanowisku agronoma gminnego. W marcu 1946 wraz z rodzicami i bratem Gabrielem wyjechał do Polski. Znalazł pracę w cukrowni Przeworno. Po kilku miesiącach trafił do Wrocławia, gdzie pracował w wojewódzkim urzędzie akcji siewnej, a następnie do 1952 był kierownikiem gospodarstwa rolnego, zaś do 1981 r., czyli do przejścia na emeryturę, głównym księgowym w państwowym gospodarstwie rolnym. Obecnie wraz z żoną Stanisławą mieszka u najmłodszej córki Małgorzaty w Siemianowicach Śląskich.

Najstarsza córka Emanuela, Elżbieta (ur. 1951), ukończyła wyższe studnia zootechniki we Wrocławiu i pracowała w PGR. Wyszła za maż za Jana Klińskiego, ma 3 synów: Aleksandra (ur. 1972), Janusza (ur. 1974) i Grzegorza (ur. 1981). Aleksander skończył technikum ekonomiczne, ożenił się z Magdaleną, ma syna Maksymiliana (ur. 1996) i córkę Elżbietę (ur. 1998). Aleksander i Magdalena pracują w prywatnej firmie drobiarskiej koło Środy Śląskiej. Janusz ukończył zawodową szkolę piekarską i wyemigrował do Niemiec, gdzie przebywa do dziś. Grzegorz ukończył technikum mechaniki samochodowej, ożenił się w Legnicy z Marzeną. Mieszkają pod Złotoryją i prowadzą prywatny zakład handlowy. W 2005 r. urodziła im się córka Maja.

Średnia córka Zofia, skończyła liceum ogólnokształcące w Środzie Śląskiej, wyszła za mąż za Zygmunta Janusa (zm. w 1996). Ma syna Tomasza, żonatego z Agnieszką, ojca Aleksandry (ur. 2000) i Damiana (ur. 2003), oraz córkę Annę, która ukończyła liceum ogólnokształcące i po odbyciu kursu bankowości pracuje w banku we Wrocławiu. Wyszła za mąż za Rafała, mają córkę Dagmarę (ur. 1996) i syna Roberta (ur. 2000).

Najmłodsza córka Emanuela, Małgorzata (ur. 1957), ukończyła liceum pielęgniarskie w Środzie Śląskiej, a następnie Wyższe Studia Pielęgniarskie na Akademii Medycznej we Wrocławiu. Wyszła za mąż za Jana Brola (ur. 1956) i ma córkę Magdalenę (ur. 1984), studentkę Uniwersytetu Śląskiego w Katowicach oraz syna Macieja (ur. 1988), studenta GWSH w Katowicach.

Trzeci syn Natalii z Firkowiczów i Rafała Abkowicza, Michał, przed wojną i w jej początkowym okresie uczył się w gimnazjum, później pracował zarobkowo w miejscowościach podwileńskich. Jesienią $1944 \mathrm{r}$. wstąpił na ochotnika do wojska polskiego i służył w nim do 1947 r. w stopniu starszego sierżanta. Po demobilizacji w 1948 przyjechał do rodziców do Wrocławia, ukończył średnią 
szkołę, a następnie Politechnikę Wrocławską, uzyskując tytuł inżyniera mechanika. Był dyrektorem technicznym we wrocławskich fabrykach. Ożenił się z Janiną, farmaceutką. Z tego związku urodziły się dwie córki: Ewa (ur. 1956) i Alina (ur. 1958). Ewa wyszła za mąż za Jerzego Włostowskiego i ma ośmioro dzieci (sześć córek i dwóch synów). Są to: Agnieszka (ur. 1980), Joanna (ur. 1981), Radosław (ur. 1983), Monika (ur. 1984), Bartosz (ur. 1985), Katarzyna (ur. 1986), Natalia (ur. 1998), Julia (ur. 2001). Agnieszka, najstarsza córka Ewy, w 2006 r urodziła córkę Klarę. Alina, absolwentka Akademii Rolniczej we Wrocławiu, jest niezamężna. Michał zmarł w 1983 r. i został pochowany we Wrocławiu.

Najmłodszy z braci Abkowiczów, Gabriel, urodzony w Łucku, po przyjeździe z Wilna do Polski zamieszkał z rodzicami we Wrocławiu, tam też ukończył szkołę średnią i wstąpił na Politechnikę Wrocławską na Wydział Lotnictwa, który po likwidacji tego wydziału we Wrocławiu - ukończył w Warszawie. Stąd został skierowany do fabryki przemysłu lotniczego w Kaliszu, gdzie przed przejściem na emeryturę zajmował stanowisko zastępcy dyrektora. Tam ożenił się z Bożeną (ur. 1940), mają córkę Agnieszkę (ur. 1968), która ukończyła studia wyższe we Wrocławiu. Wyszła za mąż i mieszka w Anglii, ma córkę Dominikę (ur. 1997) oraz Sonię, urodzoną latem 2007 r. Syn Gabriela, Wojciech (ur. 1971) ożenił się i ma troje dzieci - Bartosza (ur. 1996), Miłosza (ur. 1998) i Marcelinę (ur. 1999).

I znów wracamy do dzieci Bogusława i Kamili Firkowiczów. Ich piąte dziecko, a trzecia córka, Zuzanna (1903-1983), jak już wspominaliśmy, poślubiła w 1929 r. Gabriela (Garę) Robaczewskiego (1899-1987), byłego kadeta armii rosyjskiej, wychowanego przez ojca, pułkownika, w poszanowaniu tradycji wojskowych. Gabriel był pracownikiem poczty. Przed wojną mieszkali w miasteczku powiatowym Oszmianie, do Trok powrócili w 1942 r. Zuzanna i jej mąż mieli trzy córki: Elżbietę, Irenę i Walentynę.

Elżbieta (ur. 1930), utalentowana autorka i tłumaczka, zamężna za Ananiaszem Bezekowiczem (1925-1989), jest matką Romualda (ur. 1954), biznesmena, żonatego z Kamilą z Rojeckich (ur. 1957), ojca Karoliny (ur. 1980, zmarłej, niestety), Grety (ur. 1983) i Aureliusa (ur. 1989), mieszkającego z rodziną w Wilnie, oraz Ireny (ur. 1961), która poślubiła Aleksandra Babadżana

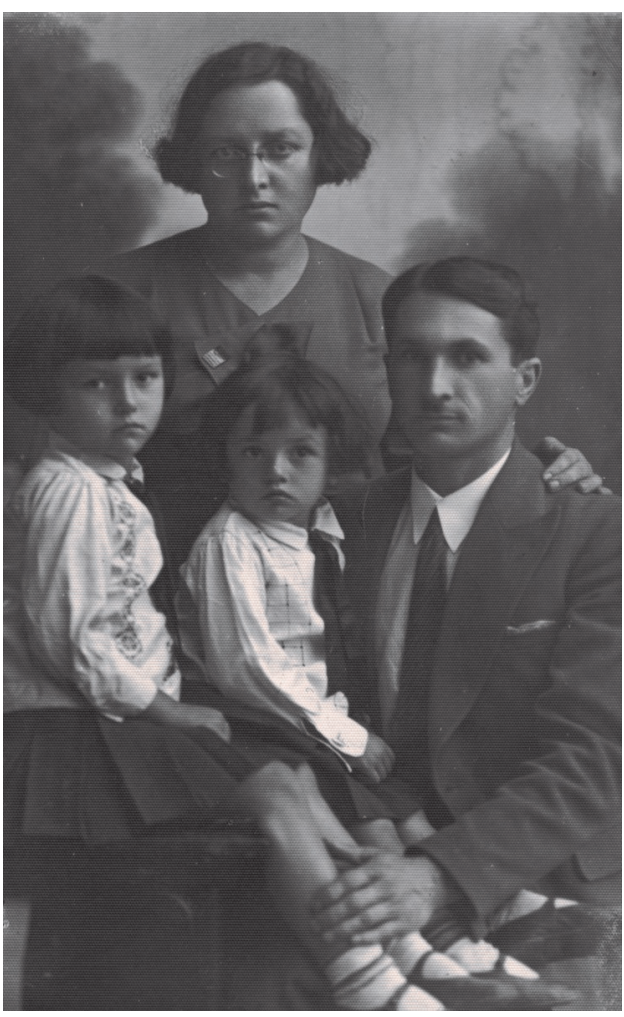

Zuzanna i Gabriel Robaczewscy ze starszymi córkami, rok 1935 
(ur. 1956), informatyka i aktywnego karaimskiego działacza społecznego. Zamieszkali w okolicach Symferopola na Krymie, mają czworo uzdolnionych artystycznie i osiągających bardzo dobre wyniki w nauce dzieci: Gariego Gabriela (ur. 1988), Wieniamina (ur. 1990), Raję Dowletę (ur. 1995) i Aleksandra (ur. 1997).

Irena (ur. 1932), nauczycielka matematyki w polskiej szkole w Wilnie, dziś już na emeryturze, gospodarzy w rodzicielskim domu w Trokach, prowadząc przy nim sprzedaż pamiątek. Jako jedyna spośród wielu potencjalnych zainteresowanych, podjęła niełatwy trud odzyskania nieruchomości (domów, sadu, ogrodów) należących ongiś do jej dziadków Kamili i Bogusława Firkowiczów, a zagarniętych przez władzę radziecką w 1941 r. Rzecz znamienna, że obecne władze wprawdzie zawzięcie krytykują sowieckie rządy i nacjonalizację, ale nic nie robią, aby wyrządzone krzywdy naprawić i zamiast zwracać odebrane dobra ich dawnym właścicielom, znacznie chętniej przekazują je nowym „osadnikom” z dalszych stron Litwy.

Trzecia córka Zuzanny, Walentyna (ur. 1935), z mężem Szymonem Pileckim ${ }^{3}$ (ur. 1927), wnukiem i synem byłych dzierżawców dawnego karaimskiego majątku w Malowance, profesorem akademii rolniczej i laureatem licznych wyróżnień, mieszkają w Kownie. Ich córka lekarka Margarita (ur. 1961), również mieszka w Kownie, natomiast druga córka, także lekarka, Regina (ur. 1968), ostatnio przeniosła się do Wilna.

Najmłodszy syn Kamili i Bogusława Firkowiczów, Michał (1908-1969), przedwojenny student prawa i tuż przed wojną urzędnik w Warszawie, później pracownik banku w Trokach, a po wojnie we Wrocławiu i Warszawie, ożenił się w 1935 r. z Tamarą Szpakowską (19102000), córką Aleksandra, długoletniego szamasza kienesy trockiej. W 1945 r. wyjechali do Polski na Dolny Śląsk, gdzie w 1946 r. spotkała ich wielka tragedia - ich syn, 4-letni Jerzy, utopił się. Zamieszkali we Wrocławiu, a w latach 60. przenieśli się do Warszawy. W 1949 r. przyszedł na świat ich drugi syn, Bogusław ${ }^{4}$ (1949-2005), absolwent Wydziału Fizyki Uniwersytetu Warszawskiego, z zamiłowania bibliofil i antykwariusz, ceniony specjalista w zakresie starodruków i rycin, znawca dzieł poświęconych tematyce karaimskiej.

I wreszcie ostatnie dziecko Kamili i Bogusława, Zinaida (1912-1988). Niezamężna, zajmowała się gospodarstwem i upra-

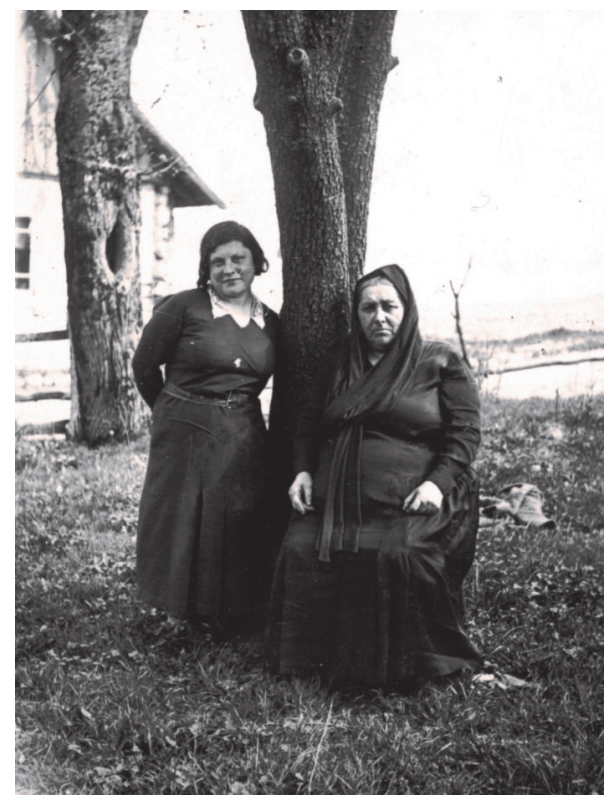

Zinaida z matka, rok 1936

3Bezekowicz E.: Szymon Pilecki, Awazymyz, nr 1 (15)/2007, s. 17-18.

4Jaroszyńska I.: Bogusław Firkowicz, Awazymyz, nr 1 (10)/2005, s. 14. 
wą ogrodu. Mieszkała w Trokach, z matką Kamilą w ich własnym murowanym domu, po nacjonalizacji gdzieś po ludziach, a w końcu u siostry Zuzanny. W czasach sowieckich pracowała $w$ trockich urzędach, była bardzo obowiązkowa, uczynna i głęboko religijna. Los nie oszczędził jej bycia świadkiem, jak aktualni „rządcy” odebranych domów, zabudowań gospodarczych i ogrodów dewastują je, doprowadzają do ruiny i niszczą, np. używając materiału z rozebranych drewnianych domów jako opału w piekarni urządzonej w murowanym domu. Gdy wzajemne odwiedziny rozdzielonych polsko-radziecką granicą krewnych stały się w latach 60. i 70. możliwe, nieraz przyjeżdżała w odwiedziny do krewnych w Warszawie i Wrocławiu.

Tak (na razie) kończy się opowieść o Dziadkach - o nich samych i pięciu pokoleniach ich potomków, którzy na przestrzeni stu lat rozproszyli się po świecie. Najbardziej chyba istotna zmiana, jaka wystąpiła podczas tych lat, dotyczy zapewne liczby członków rodziny - wiadomo, że model wielodzietności ustąpił modelowi małodzietności, czy wręcz bezdzietności.

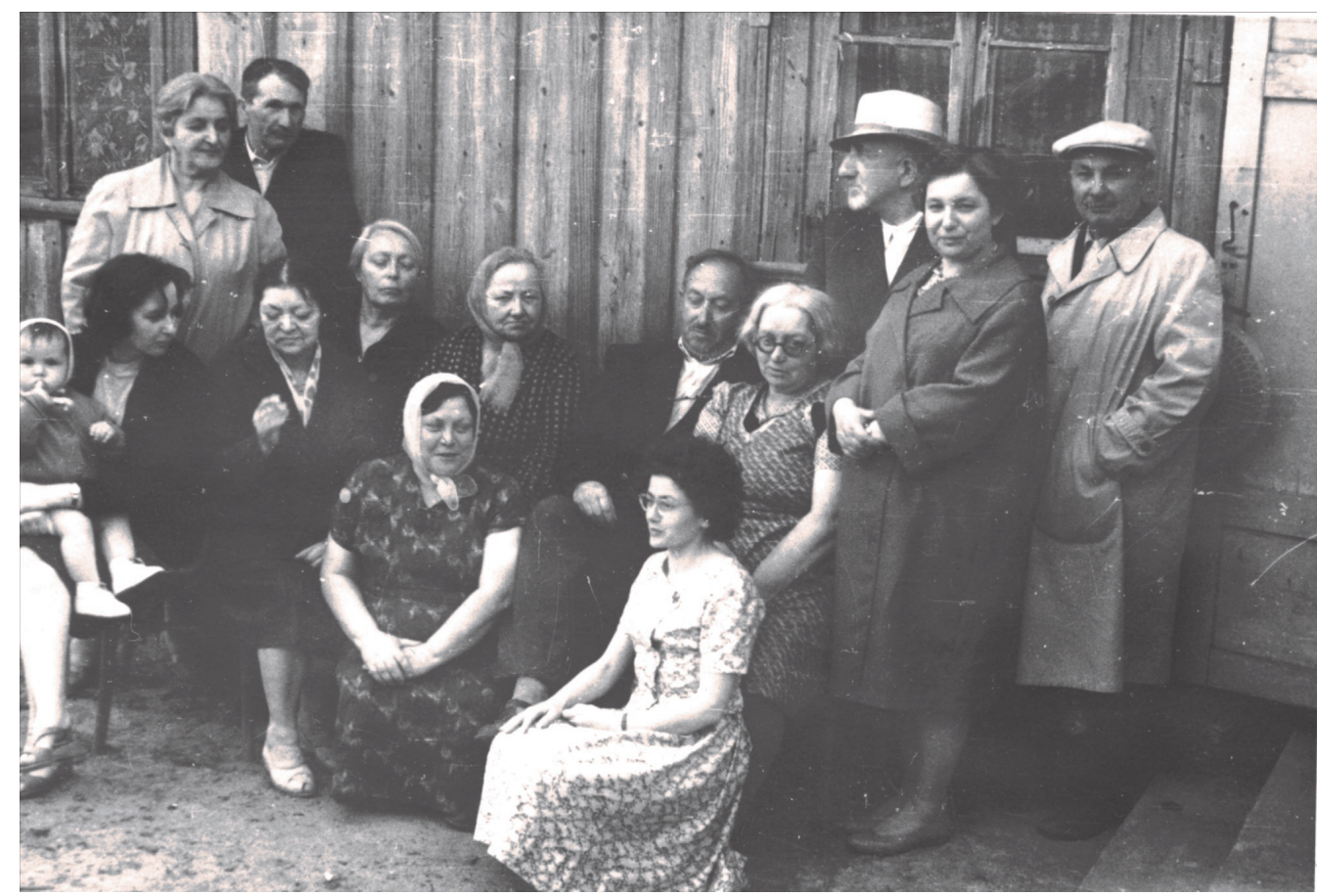

Spotkanie w Trokach, rok 1962

Chcąc naświetlić losy swych Dziadków, podczas trwania szkoły języka karaimskiego w Trokach w lipcu 2006 r. zwróciłem się do potomków Bogusława i Kamili Firkowiczów z apelem o zebranie - we własnym zakresie i odpowiednio do własnych możliwości - informacji o naszych Dziadkach. Apel ten odniósł - jak dotychczas - raczej mierny skutek, umożliwił jednak zebranie wiadomości i fotografii (niektórych nie znanych mi wcześniej) dokumentujących przeszłość. Wszystkim, którzy do tego przyczynili się, serdecznie dziękuję. Sądzę jednocze- 
śnie, że dzieło to należy kontynuować, aby wiedza o czasach minionych była coraz większa i pełniejsza. Podejmowane przez historyków próby odtwarzania minionych zdarzeń byłyby znacznie łatwiejsze i bardziej zbliżone do prawdy, gdyby ludzie pozostawiali świadectwa znanych sobie faktów, chroniąc je przed zapomnieniem, które następuje szybciej, niż się spodziewamy. 